\title{
Preparation of Functionalized Zinc and Copper Organometallics Containing Sulfur Functionalities at the Alpha or Gamma Position
}

\author{
Sidduri AchyuthaRao, Charles E. Tucker and Paul Knochel* \\ The Willard H. Dow Laboratories, Department of Chemistry, The University of Michigan \\ Ann Arbor, Michigan 48109
}

\begin{abstract}
Summary: $\alpha$-Chloroalkyl phenyl sulfides 1 readily insert zinc in THF at $25{ }^{\circ} \mathrm{C}(0.5-2 \mathrm{~h})$, affording sulfur stabilized organozinc derivatives of type 2. The presence of a functional group such as an ester or a cyano group is tolerated in these organometallics. After a transmetallation to the corresponding copper reagent 3, they react with a wide range of electrophiles. Zinc and copper organometallics bearing a thiophenyl or a phenylsulfinyl group at the $\gamma$-position have also been prepared showing the generality of our approach.
\end{abstract}

Organolithiums stabilized by sulfur ${ }^{1}$ are important carbanionic intermediates in organic synthesis. Their excellent ability to form new carbon-carbon bonds combined with the easy conversion of the sulfur group to various other functionalities has led to numerous synthetic applications. However, the high reactivity of these reagents prohibits the presence of most functional groups in these organometallics. Herein, we report a new approach to $\alpha$-thiocarbanions of zinc and copper allowing for the first time the presence of functional groups such as an ester- or a cyano-group in these compounds.

We have recently found that the presence of an oxygen at the alpha position to a carbon-halide bond considerably facilitates the insertion of zinc into this carbon-halide bond, affording organozinc halides at the alpha position to oxygen. ${ }^{2}$ We have

Scheme I

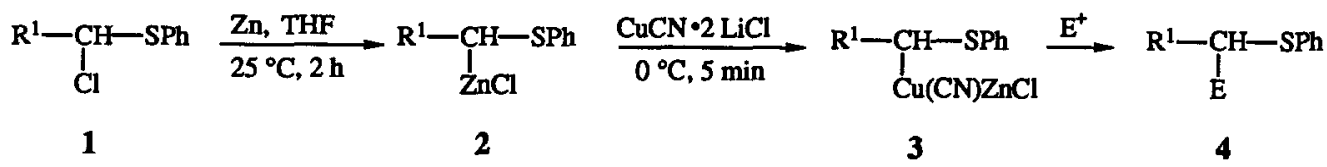

now observed that a sulfur atom exerts a similar effect and allows a very fast insertion of zinc into an adjacent carbon-chlorine bond. Thus, the treatment of an $\alpha$-chloroalkyl phenyl sulfide 3,41 with zinc dust 5 in THF at $25^{\circ} \mathrm{C}$ for $2 \mathrm{~h}$ furmishes the corresponding organozinc chloride 62 in excellent yields (>85\%). The addition of $\mathrm{CuCN} \cdot 2 \mathrm{LiCl}^{5}$ converts 2 to the copper organometallic 3 which reacts with typical organic electrophiles 7,8 leading to polyfunctional thioethers of type 4 (Table I and Scheme )..$^{9}$ The coupling of 3a with an alkynyl bromide7d gives the expected propargylic thioether $4 \mathrm{a}$ in $70 \%$ yield (1-bromooctyne $\left(0.75 \mathrm{eq}\right.$.), THF, $-60^{\circ} \mathrm{C}, 12 \mathrm{~h}$; entry 1$)$. The addition of $3 \mathrm{a}$ to benzaldehyde $(0.5 \mathrm{eq}$.) in the presence of $\mathrm{BF}_{3} \cdot \mathrm{OEt}_{2}$ (2 eq.) affords the alcohol $4 \mathrm{~b}$ in $71 \%$ yield $\left(-78{ }^{\circ} \mathrm{C}\right.$ to $-20^{\circ} \mathrm{C}, 2 \mathrm{~h}$; entry 2$)$. Allylations of the substituted copper derivatives $3 \mathrm{~b}, 3 \mathrm{~d}$, and 3 e proceed readily and in good yields $\left(75-92 \%\right.$; allylic bromide $\left(0.8 \mathrm{eq}\right.$.), $-40^{\circ} \mathrm{C}$ to $0^{\circ} \mathrm{C}, 0.5 \mathrm{~h}$; entries 3,8 and 10$)$. The Michael addition of $3 \mathrm{c}$ to 2 -cyclohexenone $\mathrm{s}^{5}(0.63 \mathrm{eq}$.) produces the desired 1,4-adduct $4 \mathrm{~d}\left(\mathrm{Me}_{3} \mathrm{SiCl}\left(2 \mathrm{eq}\right.\right.$.), THF, $-78^{\circ} \mathrm{C}$ to $25^{\circ} \mathrm{C}$, overnight; $78 \%$; entry 4). The addition-elimination of $3 \mathrm{c}$ and of the cyano-substituted organocopper $3 \mathrm{~d}$ to 3 -iodocyclohexenone ${ }^{10}$ gives the cyclohexenones $4 \mathrm{e}$ and $4 \mathrm{i}$ in $88 \%$ and $86 \%$ yields respectively $\left(-78^{\circ} \mathrm{C}\right.$ to $-20^{\circ} \mathrm{C}, 12 \mathrm{~h}$, entries 5 and 9 ). Finally, the benzoylation of $3 \mathrm{c}$ and $3 \mathrm{~d}$ affords the $\alpha$-thiophenyl ketones $4 \mathrm{f}(93 \%)$ and $4 \mathrm{~g}(79 \%)$ under mild reaction conditions (PhCOCl $\left(0.62 \mathrm{eq}\right.$.), THF, $-10^{\circ} \mathrm{C}, 12 \mathrm{~h}$; entries 6 and 7 ). 
Whereas $\beta$-sulfur-substituted zinc organometallics could not be prepared, ${ }^{11}$ certainly because of their high propensity to undergo a $\beta$-elimination, the preparation of the $\gamma$-thiophenyl and $\gamma$-phenylsulfinyl zinc reagents respectively 7 and 8 from the corresponding iodides 5 and 6 proceeds smoothly and in excellent yields (>85\%). It should be mentioned that the polar salfoxide group at the gamma position considerably facilitates the preparation of 8 (zinc dust $\left(2.5 \mathrm{eq}\right.$.), THF, $25^{\circ} \mathrm{C}, 0.5 \mathrm{~h}$ ) compared to the $\gamma$-thiophenyl-substituted derivative 7 (zinc dust ( 2.5 eq.), THF, $40^{\circ} \mathrm{C}, 3 \mathrm{~h}$ ). The addition of CuCN.2 LiCl

Table I. Products of Type 4 Obtained by the Reaction of the ( $\alpha$-Thioalkyl) Zinc and Copper Organometallics 3 with Organic Electrophiles. ${ }^{13}$

\begin{tabular}{|c|c|c|c|c|c|c|}
\hline Entry & Organometallic 3 & & Electrophile & Product of Type 4 & & Yield (\%) \\
\hline 1 & $\mathrm{PhSCH}{ }_{2} \mathrm{Cu}(\mathrm{CN}) \mathrm{ZnCl}$ & $\mathbf{3 a}$ & 1-bromooctyne & $\mathrm{PhSCH}_{2}=-\mathrm{Hex}$ & $4 a$ & 70 \\
\hline 2 & $\mathbf{3 a}$ & & $\mathrm{PhCHO}$ & $\mathrm{PhSCH}_{2} \mathrm{CH}(\mathrm{OH}) \mathrm{Ph}$ & $\mathbf{4 b}$ & 71 \\
\hline 3 & $\mathrm{PhSCH}\left(\mathrm{CH}_{3}\right) \mathrm{Cu}(\mathrm{CN}) \mathrm{ZnCl}$ & $\mathbf{3 b}$ & & & $4 c$ & 87 \\
\hline 4 & $\mathrm{PhSCH}(\mathrm{Pr}) \mathrm{Cu}(\mathrm{CN}) \mathrm{ZnCl}$ & $3 c$ & & & 4d & $78^{\mathrm{a}}$ \\
\hline 5 & $3 \mathbf{c}$ & & & & $4 e$ & 88 \\
\hline 6 & $3 c$ & & $\mathrm{PhCOCl}$ & & $4 f$ & 93 \\
\hline 7 & $\mathrm{PhSCH}\left(\mathrm{CH}_{2} \mathrm{CN}\right) \mathrm{Cu}(\mathrm{CN}) \mathrm{ZnCl}$ & 3d & Thure & & $4 g$ & 79 \\
\hline 8 & 3d & & & & 4h & 75 \\
\hline 9 & 3d & & & & $\mathbf{4 i}$ & 86 \\
\hline 10 & $\mathrm{PhSCH}\left(\left(\mathrm{CH}_{2}\right)_{2} \mathrm{CO}_{2} \mathrm{Et}\right) \mathrm{Cu}(\mathrm{CN})$ & $\mathrm{Cl} 3 e$ & & & $4 \mathbf{j}$ & 92 \\
\hline
\end{tabular}

a Product $4 \mathrm{~d}$ is obtained as a 1:1 mixture of diastereoisomers 


\section{Scheme II}

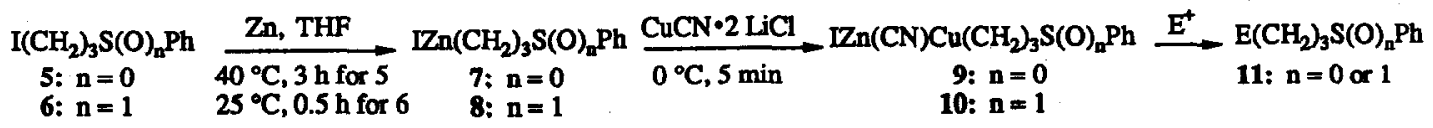

leads to the copper reagents 9 and 10 which react readily with various electrophiles (Scheme II and Table II). The allylation of 9 and 10 with tert-butyl $\alpha$-(bromomethyl)acrylate 12 (entries 1 and 5 of Table $\mathrm{I}$ ) furnishes the sulfur-substituted unsaturated esters 11a (87\%) and 11e (85\%). The Michael addition of 9 to 2 -cyclohexenone $(0.75$ eq.) gives, in the presence of chlorotrimethylsilane (2 eq.), the 3-substituted cyclohexanone $11 \mathrm{~b}$ in $84 \%$ yield $\left(-78{ }^{\circ} \mathrm{C}\right.$ to $25^{\circ} \mathrm{C}$, overnight; entry 2). The reaction of 9 with 3 -iodocyclohexenone $10(0.75 \mathrm{eq}) ;.-78{ }^{\circ} \mathrm{C}$ to $\left.-25^{\circ} \mathrm{C}, 15 \mathrm{~h}\right)$ gives the substitution product $11 \mathrm{c}$ in $85 \%$ yield (entry 3). The benzoylation of 9 leads to the ketone $11 \mathrm{~d}\left(\mathrm{PhCOCl}\left(0.75\right.\right.$ eq., $-10^{\circ} \mathrm{C}, 10 \mathrm{~h} ; 80 \%$ yield; entry 4). The stannylation of 10 with trimethyltin chloride $(0.62 \mathrm{eq}$.) gives the stannylated sulfoxide $11 \mathrm{f}$ in excellent yield (THF, $-20^{\circ} \mathrm{C}$ to $25^{\circ} \mathrm{C}, 0.5 \mathrm{~h}$; $90 \%$; entry 6 ).

Table II. Products of Type 11 Obtained by the Reaction of the Copper Reagents 9 and 10 with Organic Electrophiles. ${ }^{13}$

\begin{tabular}{|c|c|c|c|c|c|}
\hline Entry & Copper Reagent & Electrophile & Product of Type 11 & & Yield $(\%)^{2}$ \\
\hline 1 & $\mathrm{PhS}\left(\mathrm{CH}_{2}\right)_{3} \mathrm{Cu}(\mathrm{CN}) \mathrm{ZnI}$ & & & $11 \mathbf{a}$ & 87 \\
\hline 2 & 9 & & & 11b & 84 \\
\hline 3 & 9 & & & $11 \mathrm{c}$ & 85 \\
\hline 4 & 9 & $\mathrm{PhCOCl}$ & & $11 d$ & 80 \\
\hline 5 & $\mathrm{PhS}(\mathrm{O})\left(\mathrm{CH}_{2}\right)_{3} \mathrm{Cu}(\mathrm{CN}) \mathrm{ZnI}$ & & & 11e & 85 \\
\hline 6 & 10 & $\mathrm{Me}_{3} \mathrm{SnCl}$ & & $11 f$ & 90 \\
\hline
\end{tabular}


In summary, we have developed a new approach to $\alpha$-thioorganometallics of zinc and copper which for the first time can bear functional groups. This should considerably extend the synthetic potential of $\alpha$-thiocarbanions. Further new organometallic reagents of zinc and copper bearing sulfur functionalities such as thioesters, sulfones are currently being studied in our laboratories and will be reported in due course.

Acknowledgment: We thank the National Institutes of Health (GM 41908) and the Horace H. Rackham School of Graduate Studies of the University of Michigan for the generous support of this work.

\section{References and Notes}

1. (a) Corey, E.J.; Seebach, D. J. Org. Chem. 1966, 31, 4097; (b) Peterson, D.J. J. Org. Chem. 1967, 32, 1717; (c) Trost, B.M.; Keeley, D.; Bogdanowicz, M.J. J. Am. Chem. Soc. 1973, 95, 3068; (d) Watanabe, Y.; Shiono, M.; Mukaiyama, T. Chem. Lett. 1975, 871; (e) Cohen, T.; Matz, J.R. Synth. Commun. 1980, 10, 31 i; (f) Cohen, T.; Weisenfeld, J. Org. Chem. 1979, 44, 3601; (g) Hirai, K.; Matsuda, H.; Kishida, Y. Tetrahedron Lett. 1971, 4359; (h) Hirai, K.; Kishida, Y. ibid 1972, 2743; (i) Meyers, A.I.; Ford, M.E. J. Org. Chem. 1976, 41, 1735; (j) Wartski, L.; El Bouz, M.; Seyden-Penne, J.; Dumont, W.; Krief, A. Tetrahedron Lett. 1979, 1543; (k) Johnson, C.R.; Nakanishi, A.; Nakanishi, N.; Tanaka, K. Tetrahedron Lett. 1975, 2865; (1) Negishi, E.; Yoshida, T.; Silveira, A.; Chiou, B.L. J. Org. Chem. 1975, 40, 814; (m) Reitz, D.B.; Beak, P.; Farney, R.F.; Helmick, L.S.J. Am. Chem. Soc. 1978, 100, 5428.

2. (a) Knochel, P.; Chou, T.-S.; Chen, H.G.; Yeh, M.C.P.; Rozema, M.J. J. Org. Chem. 1989, 54, 5202; (b) Chou, T.-S.; Knochel, P. J. Org. Chem. 1990, 55, 4791.

3. The $\alpha$-chloroalkyl phenyl sulfides $1 \mathrm{~b}$-le were prepared by chlorination of the corresponding alkyl phenyl sulfides with recrystallized N-chlorosuccinimide according to literature procedures. For a review, see: Dilworth, B.M.; McKervey, M.A. Tetrahedron 1986 42, 3731.

4. The in situ generated $\alpha$-iodo sulfides have been shown to insert chromium(II) chloride affording $(\alpha$-thioalkyl)chrominum(III) reagents: Nakatsukasa, S.; Takai, K.; Utimoto, K. J. Org. Chem. 1986, $51,5045$.

5. The zinc dust (Aldrich, -325 mesh) has been activated with 3-5\% of 1,2-dibromoethane according to: Knochel, P.; Yeh, M.C.P.; Berk, S.C.; Talbert, J. J. Org. Chem. 1988, 53, 2390.

6. Bis-(thiophenylmethyl)zinc has been prepared previously by the reaction of zinc with bis-(thiophenylmethyl)mercury: Taube, R.; Steinborn, D. J. Organomet. Chem. 1974, 65, C9.

7. (a) Yeh, M.C.P.; Knochel, P. Tetrahedron Lett. 1988, 29, 2395; (b) Majid, T.N.; Yeh, M.C.P.; Knochel, P. Tetrahedron Lett. 1989, 30, 5069; (c) Yeh, M.C.P.; Knochel, P.; Santa, L.E. Tetrahedron Lett. 1988, 29, 3887; (d) Yeh, M.C.P.; Knochel, P. Tetrahedron Lett. 1989, 30, 4799.

8. The copper reagents 3 were found to be less reactive than $R C u(C N) Z n I(R=a l k y l$, prim. or sec.) and no reaction was observed with diethyl benzylidenemalonate or nitrostyrene.

9. Typical procedure: (a) Preparation of 2-cyano-1-phenylthioethylzinc chloride 2d. A $50 \mathrm{~mL}$, three-necked flask equipped with a droppping funnel, a thermometer and an argon inlet was charged with zinc dust (Aldrich, $-325 \mathrm{mesh}, 1.95 \mathrm{~g}, 30 \mathrm{mmol}$ ) in $2 \mathrm{~mL}$ of THF. After zinc activation with dibromoethane (ca. 300 $\mathrm{mg}$; see ref. 5), a solution of 3-chloro-3-phenylthiopropionitrile $(1.98 \mathrm{~g}, 10 \mathrm{mmol})$ in $6 \mathrm{~mL}$ of THF was added at 25 ${ }^{\circ} \mathrm{C}$. After $2 \mathrm{~h}$ at $25^{\circ} \mathrm{C}$, GLC analysis of a hydrolyzed aliquot showed no chloride remaining. The reaction mixture was allowed to settle.

(b) Reaction of 2d with 3-iodocyclohexenone: 10 preparation of 3-(2-cyano-1-phenylthicethyl)cyclohexenone 4i (entry 9 of Table I). The supernatant solution of the organozinc chloride prepared above was transferred via syringe to a solution of dry $\mathrm{LiCl}$ (dried for $1 \mathrm{~h}$ at $120^{\circ} \mathrm{C}$ at $0.1 \mathrm{mmHg} ; 0.68 \mathrm{~g} ; 16 \mathrm{mmol}$ ) and CuCN $(0.72 \mathrm{~g}, 8 \mathrm{mmol}$ ) in 6 $\mathrm{mL}$ of THF at $-40^{\circ} \mathrm{C}$. The resulting greenish suspension was warmed to $0^{\circ} \mathrm{C}$ and stirred for $5 \mathrm{~min}$. After cooling to $-70^{\circ} \mathrm{C}$, a solution of 3-iodocyclohexenone $(1.11 \mathrm{~g}, 5 \mathrm{mmol})$ in $2 \mathrm{~mL}$ of THF was added and the reaction was allowed to warm to $0{ }^{\circ} \mathrm{C}$ and was stirred at this temperature for $12 \mathrm{~h}$. After a standard workup procedure, the residue obtained after evaporation of the solvents was purified by flash chromatography (solvent: 1:3 ratio of ethyl acetate and hexane) providing $1.1 \mathrm{~g}$ (86\% yield) of the analytically pure cyclohexenone derivative $4 \mathrm{i}$.

10. Piers, E.; Nagakura, I. Synth. Comm. 1975, 5, 193.

11. Attempts to prepare the zinc organometallic corresponding to 2-iodoethylisopropylsulfoxide were unsuccessful.

12. tert-Butyl $\alpha$-(bromomethyl)acrylate was prepared according to: Villieras, J.; Rambaud, M. Synthesis 1982924.

13. All yields refer to isolated yields of analytically pure products. Satisfactory spectral data (IR, $1_{H}$ and ${ }^{13} \mathrm{C} N M R$, mass spectra, high resolution mass spectra) has been obtained for all compounds. 